\title{
Gene polymorphism analysis of Yersinia enterocolitica outer membrane protein A and putative outer membrane protein $A$ family protein
}

\author{
Kewei $\mathrm{Li}^{1 \dagger}$, Wenpeng $\mathrm{Gu}^{2+}$, Junrong Liang ${ }^{1+}$, Yuchun Xiao ${ }^{1}$, Haiyan $\mathrm{Qiu}^{1}$, Haoshu Yang ${ }^{1}$, Xin Wang ${ }^{1}$
} and Huaiqi Jing ${ }^{1 *}$

\begin{abstract}
Background: Yersinia enterocolitica outer membrane protein A $(\mathrm{OmpA})$ is one of the major outer membrane proteins with high immunogenicity. We performed the polymorphism analysis for the outer membrane protein $\mathrm{A}$ and putative outer membrane protein A ( $p$-ompA) family protein gene of $318 \mathrm{Y}$. enterocolitica strains.

Results: The data showed all the pathogenic strains and biotype $1 A$ strains harboring ystB gene carried both ompA and $p$-ompA genes; parts of the biotype 1A strains not harboring ystB gene carried either ompA or $p$-ompA gene. In non-pathogenic strains (biotype 1A), distribution of the two genes and yst $B$ were highly correlated, showing genetic polymorphism. The pathogenic and non-pathogenic, highly and weakly pathogenic strains were divided into different groups based on sequence analysis of two genes. Although the variations of the sequences, the translated proteins and predicted secondary or tertiary structures of OmpA and P-OmpA were similar.
\end{abstract}

Conclusions: OmpA and $p$-ompA gene were highly conserved for pathogenic $Y$. enterocolitica. The distributions of two genes were correlated with ystB for biotype $1 A$ strains. The polymorphism analysis results of the two genes probably due to different bio-serotypes of the strains, and reflected the dissemination of different bio-serotype clones of $Y$. enterocolitica.

Keywords: Yersinia enterocolitica, ompA, $p$-ompA, ystB

\section{Background}

$Y$. enterocolitica is spread primarily through contaminated food or water [1] and causes a wide range of intestinal diseases, including enteritis, mesenteric lymphadenitis, and sepsis in some severe cases; and also cause some complications such as erythema nodosum and reactive arthritis [2]. Currently, $Y$. enterocolitica is divided into six biotypes $(1 \mathrm{~A}, 1 \mathrm{~B}$, and $2-5)$ and more than 50 serotypes [3]. The biotypes of $Y$. enterocolitica are divided into three groups according to the bacterial pathogenic properties: non-pathogenic biotype $1 \mathrm{~A}$, weakly pathogenic biotypes $2-5$, and highly pathogenic biotype $1 \mathrm{~B}$ [4]. At present, the virulent factors of $Y$. enterocolitica

\footnotetext{
* Correspondence: jinghuaiqi@icdc.cn

${ }^{\dagger}$ Equal contributors

${ }^{1}$ National Institute for Communicable Disease Control and Prevention, Chinese Center for Disease Control and Prevention, State Key Laboratory for Infectious Disease Prevention and Control, Collaborative Innovation Center for Diagnosis and Treatment of Infectious Diseases, 102206 Beijing, China Full list of author information is available at the end of the article
}

are mainly referred to type III secretion system (TTSS) encoded by 70-kb plasmid pYV [3,5], Yersinia adhesin A (YadA), the virulence genes involved inv (invasion gene), ail (attachment and invasion locus gene), yst (Yersinia stable toxin gene), myfA (mucoid Yersinia factor gene) and the pathogenic island (HPI), etc. [6]. Biotype 1A strains are traditionally considered non-pathogenic, however in recent studies have confirmed that a portion of them can cause clinical symptoms similar to pathogenic strains [7].

Bacterial outer membrane proteins primarily contain outer membrane protein $\mathrm{A}$, porin $\mathrm{C}$ and $\mathrm{F}$, being the major immunogenic proteins, and widely present in Gram-negative Enterobacteriaceae [8]. Recently, multifunction of outer membrane protein $\mathrm{A}$ of intestinal bacteria has been demonstrated [9-12], but seldom referred to $Y$. enterocolitica. In our previous study [13], OmpA was the major immunogenic protein of both highly and weakly pathogenic $Y$. enterocolitica incubated at different temperatures. To further identify the

\section{Biomed Central}

(c) 2014 Li et al.; licensee BioMed Central Ltd. This is an Open Access article distributed under the terms of the Creative Commons Attribution License (http://creativecommons.org/licenses/by/2.0), which permits unrestricted use, distribution, and reproduction in any medium, provided the original work is properly credited. 
characteristics of ompA for $Y$. enterocolitica, we sequenced and analyzed the polymorphism of $\operatorname{omp} A$ (and p-ompA) genes of $Y$. enterocolitica.

\section{Results}

Distribution of ompA and $p$-ompA genes

The ompA and p-ompA genes were detected in 318 $Y$. enterocolitica strains. The data showed 170 of all the pathogenic strains carried both ompA and $p$-ompA; 91 biotype 1A strains carried ompA, and 106 carried $p$-ompA (Table 1). The ompA and $p$-ompA genes were both existed for biotype $1 \mathrm{~A}$ strains carried $y s t B$ gene. However, the isolates only had one of the two genes for biotype $1 \mathrm{~A}$ strains without $y s t B$ gene. The distribution of the two genes was associated with $y s t B$, especially for $o m p A$ (Tables 2 and 3). The correlation analysis $(\mathrm{P}<0.05)$ showed correlation coefficient (r) was 0.67 between $o m p A$ and $y s t B$ and 0.58 between $p$-ompA and $y s t B$.

\section{Polymorphism analysis of the two genes}

ompA: The Open Reading Frame (ORF) of ompA was 1,074 bp encoding 357 amino acids (Genbank: YP_00 1005874.1). The ompA gene of 261 strains formed 23 sequence types. The pathogenic group contained five types, Pattern A-E (Figure 1A). 155 pathogenic strains (76 bio-serotype 3/O: 3, two 4/O: 3, 68 2/O: 9, one 4/O: 9 and eight 3/O: 9) were clustered into Pattern A, and accounted for $91.2 \%$ of all of the pathogenic strains. Therefore, pattern A was an absolute primary type in all pathogenic isolates. Other nine pathogenic strains were clustered into pattern $\mathrm{B}$ and $\mathrm{C}$, seven (two bio-serotype 2/O: 3, four 4/O: 3 and one 3/O: 9) were clustered into Pattern C, two pathogenic bio-serotype 2/O: 5, 27 clustered into pattern $\mathrm{B}$. Few nucleotide differences were found between pattern A and B (Figure 2); while the nucleotide insertion was found compared with pattern $\mathrm{A}$ and $\mathrm{C}$ (Figure 3 ). Six highly pathogenic bio-serotype 1B/O: 8 strains were clustered into Patterns D and E (Figure 1A), and the nucleotide differences were shown with red bases compared with pattern A and B (Figure 2).

The non-pathogenic group contained 91 biotype 1A strains, formed 18 sequence types, Pattern F-W; all the 83

Table 1 Distribution of ompA and p-ompA gene in all strains

\begin{tabular}{|c|c|c|c|c|c|}
\hline & \multicolumn{2}{|c|}{ ompA+ } & \multicolumn{2}{|c|}{ ompA- } & \multirow[t]{2}{*}{ Total } \\
\hline & p-ompA+ & p-ompA- & p-ompA+ & p-ompA- & \\
\hline Pathogenic strains & 170 & 0 & 0 & 0 & 170 \\
\hline $\begin{array}{l}\text { Biotype } 1 \mathrm{~A} \\
\text { strains ystB+}\end{array}$ & 84 & 0 & 0 & 0 & 84 \\
\hline $\begin{array}{l}\text { Biotype } 1 \mathrm{~A} \\
\text { strains ystB- }\end{array}$ & 0 & 7 & 22 & 35 & 64 \\
\hline Total & 254 & 7 & 22 & 35 & 318 \\
\hline
\end{tabular}

+: positive; -: negative.
Table 2 Distribution of ompA and yst $B$ gene in biotype 1 A strains

\begin{tabular}{lcccc}
\hline ompA & \multicolumn{2}{c}{ yst } & & Total \\
\cline { 2 - 3 } & + & - & \\
\hline+ & 84 & 7 & 91 \\
- & 0 & 57 & 57 \\
Total & 84 & 64 & 148 \\
\hline
\end{tabular}

+: positive; -: negative.

strains carried the $y s t B$ gene were clustered into pattern F-T; Eight strains (except one) without ystB gene formed pattern U-W (Figure 1A).

There were nucleotide fragment insertions and deletions for ompA gene sequences. The nucleotide fragment insertion was found for pattern $C$. The insertion site located at 659-664 nt of the ORF with the "-CTCCAG-" compared with pattern A (Figure 3I), this made an alanine (A) and a proline (P) inserted at position 220 and 221 in the amino acid sequence of the OmpA. For biotype 1A strains, sequence type diversities were found compared with pathogenic strains, and the nucleotide fragment deletions were observed for pattern $U$ to $W$. 15 nucleotides deletions located at 140-154 nt with "-TCTATGGCGACCAAG-", and 6 nucleotides deletions located at 409-414 nt with "-GACGCA-" of ompA were found (Figure 3D). Eventually, this led to a change of the amino acid of the OmpA at sites 39-52, 94-98,133-146, included amino acid deletions or translation into other amino acids.

Although some predicted amino acid differences were found for ompA of $Y$. enterocolitica, the primary proteins and its functions were the same, even if the insertions of the pathogenic or deletions of the non-pathogenic strains occurred. For all the $Y$. enterocolitica possessed ompA in this study, the translated proteins were identical. The predicted secondary structure of OmpA for all the strains were almost the same, and the predicted tertiary structure of OmpA for all the isolates were similar as well. It was highly conserved for the structure and function of OmpA for $Y$. enterocolitica, no matter the pathogenic ability and other characteristics.

p-ompA: The Open Reading Frame (ORF) of $p$-ompA was 1,377 bp encoding 458 amino acids (GenBank:

Table 3 Distribution of $p$-ompA and yst $B$ gene in biotype 1 A strains

\begin{tabular}{lcccc}
\hline $\boldsymbol{p}$-ompA & \multicolumn{2}{c}{ yst $\boldsymbol{B}$} & Total \\
\cline { 2 - 4 } & + & - & \\
\hline+ & 84 & 22 & 106 \\
- & 0 & 42 & 42 \\
Total & 84 & 64 & 148 \\
\hline
\end{tabular}

+: positive; -: negative. 


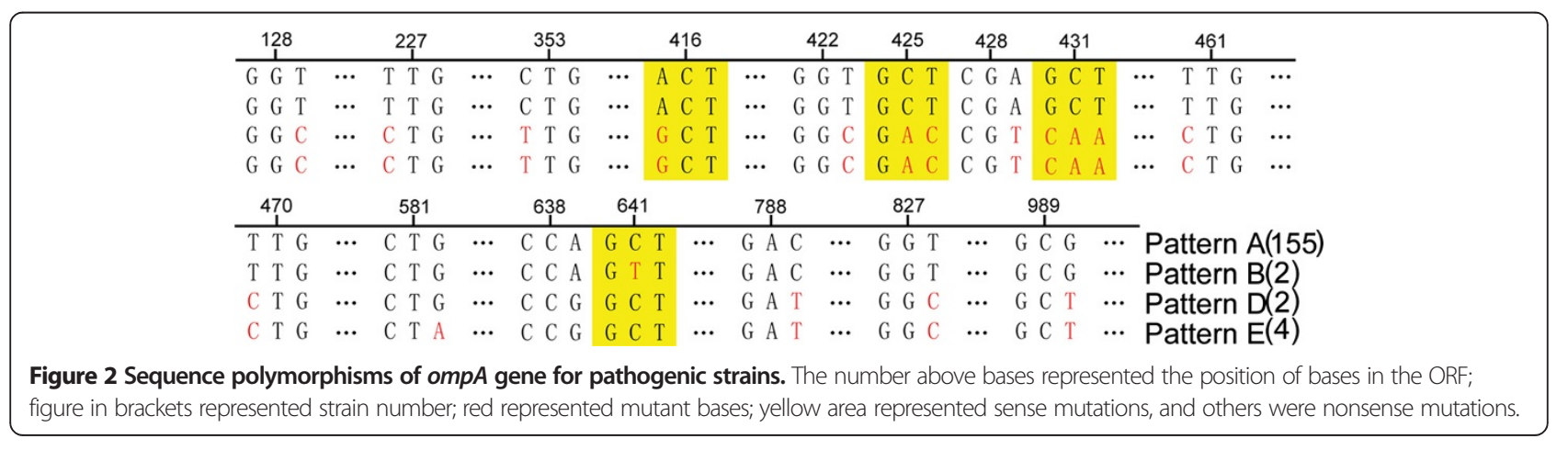




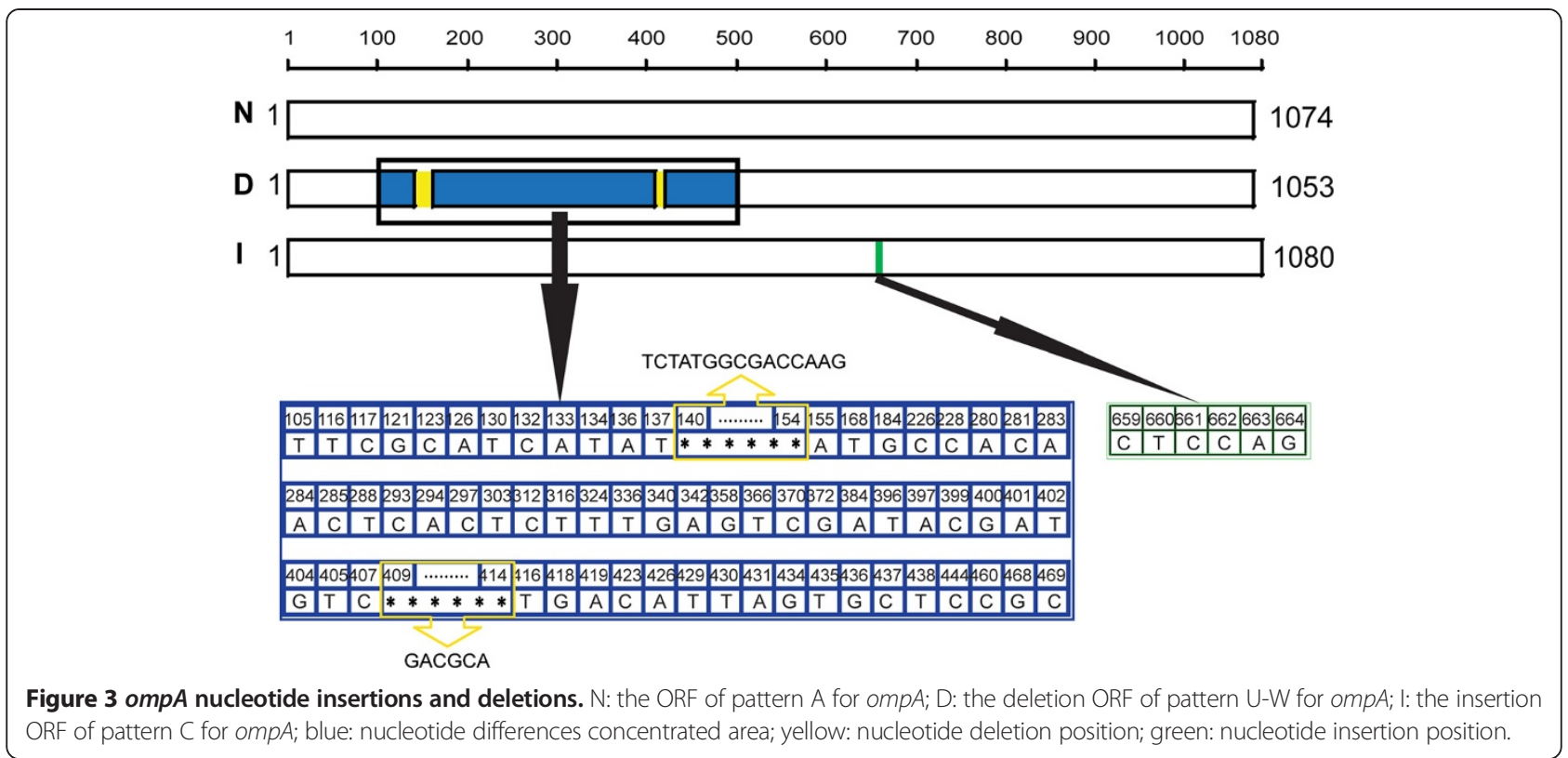

YP_001006877.1). P-ompA genes were existed among 276 $Y$. enterocolitica, 170 pathogenic and 106 biotype $1 \mathrm{~A}$ strains (84 carried $y s t B$ gene and 22 without). The $p$-omp $A$ genes were clustered into 38 sequence types, divided into pathogenic and non-pathogenic group (Figure 1B). Pattern 1-7 belonged to pathogenic group, included all the 170 pathogenic strains and three bio-serotype 1A/O: 3 isolates. Pattern 3 and pattern 7 were the primary types for the pathogenic strains, 67 bio-serotype 2/O: 9, eight 3/O: 9, one 4/O: 9 and three bio-serotype 1A/O: 3 strains formed pattern 3; 75 bio-serotype 3/O: 3, one 2/O: 3, four 4/O: 3 and one 3/O: 9 formed pattern 7. Pattern 5 contained two bio-serotype 4/O: 3 , one 3/O: 3 and one 2/O: 9 strains; pattern 6 contained only one 2/O: 3 isolate; two bioserotype 2/O: 5, 27 strains formed pattern 4, and six highly pathogenic 1B/O: 8 strains formed pattern 1 and 2 .

\begin{tabular}{|c|c|c|c|c|c|c|c|c|c|c|c|c|c|c|c|c|}
\hline 11 & & 26 & & 113 & & 155 & & 194 & & 335 & & 419 & & 503 & 668 & \\
\hline$A G C$ & $\cdots$ & $\mathrm{CCA}$ & $\cdots$ & G G T & $\cdots$ & C A T & $\cdots$ & $\mathrm{ACC}$ & $\cdots$ & $\mathrm{CAT}$ & $\cdots$ & $\mathrm{GCC}$ & $\cdots$ & $A G C$ & $\begin{array}{llll}\cdots & \text { G G T }\end{array}$ & $\cdots$ \\
\hline$A G C$ & $\cdots$ & $\mathrm{C} C \mathrm{~A}$ & $\cdots$ & G G T & $\cdots$ & $C A C$ & $\cdots$ & $\mathrm{ACC}$ & $\cdots$ & $C A G$ & $\ldots$ & $\mathrm{GCC}$ & $\cdots$ & $A G C$ & $\cdots \quad G G T$ & $\cdots$ \\
\hline$A G T$ & $\cdots$ & C C T & $\cdots$ & A G T & $\cdots$ & $\mathrm{CAC}$ & $\cdots$ & $\mathrm{A} C \mathrm{C}$ & $\cdots$ & $\mathrm{CA} \mathrm{G}$ & $\cdots$ & $\mathrm{GC} \mathrm{G}$ & $\cdots$ & $A G C$ & G G T & $\cdots$ \\
\hline$A G T$ & $\ldots$ & $\mathrm{C} C \mathrm{~T}$ & $\cdots$ & $A G T$ & $\ldots$ & $\mathrm{CAC}$ & $\cdots$ & $\mathrm{ACC}$ & $\cdots$ & $C A G$ & $\ldots$ & $\mathrm{GC} \mathrm{G}$ & $\cdots$ & $A G C$ & $G G T$ & $\ldots$ \\
\hline$A G T$ & $\cdots$ & C C T & $\cdots$ & $A G T$ & $\cdots$ & $\mathrm{CAC}$ & $\cdots$ & $\mathrm{ACC}$ & $\cdots$ & $C A G$ & $\cdots$ & $\mathrm{GC} \mathrm{G}$ & $\cdots$ & A G T & $\mathrm{A} G \mathrm{~T}$ & $\cdots$ \\
\hline$A G T$ & $\cdots$ & C C T & $\cdots$ & $A G T$ & $\cdots$ & $\mathrm{CAC}$ & $\cdots$ & A T C & $\cdots$ & $C A G$ & $\cdots$ & $\mathrm{GC} \mathrm{G}$ & $\cdots$ & $\mathrm{A} G \mathrm{C}$ & $G G T$ & $\cdots$ \\
\hline$A G T$ & $\cdots$ & $\mathrm{C} C \mathrm{~T}$ & $\cdots$ & $A G T$ & $\cdots$ & $\mathrm{CAC}$ & $\cdots$ & $\mathrm{ACC}$ & $\cdots$ & $C A G$ & $\cdots$ & $\mathrm{GC} \mathrm{G}$ & $\cdots$ & $A G C$ & $G G T$ & $\cdots$ \\
\hline 704 & & 731 & & 740 & & 785 & & 794 & & 887 & & 893 & & 908 & 914 & \\
\hline T T G & $\cdots$ & $\mathrm{ACC}$ & $\cdots$ & $\mathrm{ACC}$ & $\cdots$ & $\mathrm{AAG}$ & $\cdots$ & A T C & $\cdots$ & $\mathrm{AGC}$ & $\cdots$ & C T G & $\cdots$ & G C A & $\begin{array}{cccc}\cdots & \text { T } & \text { T }\end{array}$ & $\cdots$ \\
\hline $\mathrm{T} \mathrm{T} \mathrm{G}$ & $\cdots$ & $\mathrm{ACC}$ & $\cdots$ & $\mathrm{ACC}$ & $\cdots$ & $A A G$ & $\cdots$ & $\mathrm{A} \mathrm{T} \mathrm{C}$ & $\cdots$ & $A G C$ & $\cdots$ & C T G & $\cdots$ & $\mathrm{GCA}$ & $\mathrm{T} \mathrm{T} \mathrm{G}$ & ... \\
\hline C T G & $\cdots$ & $\mathrm{A} C \mathrm{~T}$ & $\cdots$ & $\mathrm{A} C \mathrm{~T}$ & $\cdots$ & $A G G$ & $\cdots$ & A T T & $\cdots$ & $A G T$ & $\cdots$ & $\mathrm{T} \mathrm{T} \mathrm{G}$ & $\cdots$ & $G A A$ & C T G & $\cdots$ \\
\hline $\mathrm{C} \mathrm{T} \mathrm{G}$ & $\cdots$ & $\mathrm{A} C \mathrm{~T}$ & $\cdots$ & $\mathrm{A} C \mathrm{~T}$ & $\cdots$ & $A G G$ & $\cdots$ & $\mathrm{AT} \mathrm{T}$ & $\cdots$ & $A G T$ & $\cdots$ & T T G & $\cdots$ & $\mathrm{GAA}$ & C T G & $\cdots$ \\
\hline C T G & $\cdots$ & A C T & $\cdots$ & A C T & $\cdots$ & $A G G$ & $\cdots$ & A T C & $\cdots$ & $A G T$ & $\cdots$ & $\mathrm{T} \mathrm{T} \mathrm{G}$ & $\cdots$ & $\mathrm{GAA}$ & C T G & $\cdots$ \\
\hline C T G & $\ldots$ & $\mathrm{AC} \mathrm{T}$ & $\cdots$ & $\mathrm{AC} \mathrm{T}$ & $\cdots$ & $A G G$ & $\cdots$ & $\mathrm{ATC}$ & $\cdots$ & $A G T$ & $\cdots$ & T T G & $\cdots$ & G A A & C T G & $\cdots$ \\
\hline C T G & $\cdots$ & $\mathrm{A} C \mathrm{~T}$ & $\cdots$ & $\mathrm{A} C \mathrm{~T}$ & $\cdots$ & $A G G$ & 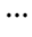 & $\mathrm{A} \mathrm{T} \mathrm{C}$ & $\cdots$ & $A G T$ & & T T G & $\cdots$ & G A A & $\cdots \quad$ C T G & $\cdots$ \\
\hline 932 & & 992 & & 1025 & & 1085 & & 1169 & & $\underset{1250}{125}$ & & \multirow{8}{*}{\multicolumn{3}{|c|}{$\begin{array}{l}\text { Pattern 1(1) } \\
\text { Pattern 2(5) } \\
\text { Pattern 3(79) } \\
\text { Pattern 4(2) } \\
\text { Pattern 5(4) } \\
\text { Pattern 6(1) } \\
\text { Pattern 7(81) }\end{array}$}} & & \\
\hline GT G & .. & $A A G$ & $\cdots$ & $\mathrm{C} \mathrm{GC}$ & $\cdots$ & T C C & & T C T & $\cdots$ & $\mathrm{GAG}$ & & & & & & \\
\hline G T G & $\cdots$ & $A A G$ & $\cdots$ & $\mathrm{C} \mathrm{GC}$ & $\cdots$ & $\mathrm{T} \mathrm{C} \mathrm{C}$ & & $\mathrm{T} C \mathrm{~T}$ & $\cdots$ & $\mathrm{GA} \mathrm{G}$ & & & & & & \\
\hline G T A & $\cdots$ & $A A G$ & $\cdots$ & $\mathrm{CAC}$ & $\cdots$ & $\mathrm{CCC}$ & . & G C T & $\cdots$ & $\mathrm{GAA}$ & & & & & & \\
\hline G T A & $\cdots$ & A A A & $\cdots$ & $\mathrm{CAC}$ & $\cdots$ & $\mathrm{CCC}$ & $\cdots$ & $\mathrm{T} C \mathrm{~T}$ & $\cdots$ & GA A & & & & & & \\
\hline G T A & $\cdots$ & $A A G$ & $\cdots$ & $\mathrm{CAC}$ & $\cdots$ & $\mathrm{CCC}$ & . & $\mathrm{T} C \mathrm{~T}$ & $\cdots$ & $\mathrm{GAA}$ & & & & & & \\
\hline G T A & $\cdot$ & $A A G$ & $\cdots$ & $\mathrm{CAC}$ & $\cdots$ & $\mathrm{CCC}$ & * & $\mathrm{T} C \mathrm{~T}$ & $\cdots$ & $\mathrm{GAA}$ & & & & & & \\
\hline G T A & $\cdots$ & $\mathrm{A} A \mathrm{G}$ & $\cdots$ & $\mathrm{CAC}$ & $\cdots$ & $\mathrm{C} \mathrm{C} \mathrm{C}$ & . & $\mathrm{TCT}$ & $\cdots$ & $G A A$ & & & & & & \\
\hline
\end{tabular}

Figure 4 Sequence polymorphisms of $\boldsymbol{p}$-ompA gene for pathogenic strains. The number above the bases represented position of the bases in the ORF; figure in brackets represents the strain number; red represented mutant bases; yellow area represented sense mutations, and others were nonsense mutations. 
Some nucleotide point mutants were found among pattern 1 to 7 , as shown in Figure 4.

Pattern 8-38 referred to non-pathogenic group, included 106 biotype $1 \mathrm{~A}$ strains. All of the 84 isolates carried $y s t B$ were clustered into pattern 8 to $27 ; 22$ strains without $y s t B$ were clustered into pattern 28 to 38 (Figure $1 B$ ).

Although the diversity of cluster results was found for $p$-ompA, the primary proteins structure and function of different patterns were identical predicted by software. The predicted secondary and tertiary structure or functions of proteins for all patterns were also similar, shown the conservative characteristic.

\section{Discussions}

The surface structures of bacterial pathogens (including pilus, flagella, outer membrane proteins, and various secretion systems) are likely to interact with host tissue to regulate adhesion and invasion [14]. The outer membrane protein A belong to highly conserved protein in intestinal bacteria, and play a key role in bacterial integrity and virulence [15]. Currently, more evidence shows the pathogenicity of outer membrane protein $\mathrm{A}$ in a variety of pathogens [11,16-19].

In our study, all the 170 pathogenic $Y$. enterocolitica strains carried the ompA and $p$-ompA genes. Few nucleotides changes were found for both ompA and $p$-ompA of the pathogenic strains. Therefore, the distributions of two genes were highly conserved for pathogenic $Y$. enterocolitica. The translated proteins or predicted structures of different patterns of the two genes were the same, certificated the conservative property of $o m p A$ and $p$-ompA for $Y$. enterocolitica. Several researches had been widely shown the distribution of outer membrane protein A among entero-pathogenic bacteria, and its important role in bacterial infection and immunogenicity [16-19]. However, seldom study referred to ompA or $p$-ompA of $Y$. enterocolitica, so it was the first time to perform this research. Our results showed the pathogenic strains and non-pathogenic strains were divided into different groups, and highly or weakly pathogenic strains were also distinguished based on sequence results of two genes, which reflected the different bio-serotype distributions of $Y$. enterocolitica. In China, serotype O: 3 and O: 9 strains were predominate pathogenic $Y$. enterocolitica, and most of these bacteria isolated from patients, swine and dogs. While, non-pathogenic strains referred to biotype $1 \mathrm{~A}$, and widely distributed among different hosts. Furthermore, no highly pathogenic $1 \mathrm{~B} / \mathrm{O}: 8$ strain was isolated in China up to present, all the highly pathogenic 1B/O: 8 were foreign strains in our study. Additionally, the weakly pathogenic strains (biotype 2-4, serotype O: 3 or O: 9 strains) included wild strains from China and reference strains not from China showed no differences even if they were isolated from different origins in our study. Therefore, the cluster results for ompA or $p$-ompA explained the different bio-serotype distributions of $Y$. enterocolitica. Highly pathogenic biotype 1B strains have been shown to differ genetically from weakly pathogenic biotype 2-4 strains, and they belonged to different subtypes. The polymorphism analysis results of the two genes probably reflected the dissemination of different bio-serotype clones of $Y$. enterocolitica for a period of time.

Biotype 1A strains lack pYV plasmid and chromosomal virulence genes, and generally regarded as avirulent [1]. However, few studies have confirmed biotype 1A strains were related to outbreaks of nosocomial infections and foodborne diarrhea [20,21]; and some early studies found that biotype $1 \mathrm{~A}$ strains could cause abortion in goats and cattle [22-25]. Grant et al. [26,27] showed biotype $1 \mathrm{~A}$ strains invaded epithelial cells and resisted the killing effect of macrophage. Also biotype 1A strains were associated with the potential pathogenicity in humans [28]. Enterotoxin is an important pathogenic factor in most enteric pathogens, and the $y s t B$ gene coded for a class of thermo-resistant enterotoxin in biotype 1A $Y$. enterocolitica $[29,30]$. Virulence related gene $y s t B$ was a distinguishing marker of biotype $1 \mathrm{~A}$ strains, presented in close to $100 \%$ of clinical isolates [31,32]. However, whether $y s t B$ gene as a virulent factor for biotype $1 \mathrm{~A}$ of $Y$. enterocolitica has not been confirmed. Nakano et al. [33] found Salmonella enterotoxin (stn) regulated the OmpA membrane localization and functions, indicated the close relationship between them. In our research, omp $A$ and $p$-ompA were correlated with $y s t B$ in biotype $1 \mathrm{~A}$ strains, and formed the independent cluster patterns, the strains with $y s t B$ or without $y s t B$ for biotype $1 \mathrm{~A}$ were also separated, which indicated the phenomenon that OmpA was linked with enterotoxins for $Y$. enterocolitica biotype $1 \mathrm{~A}$ strains.

\section{Conclusions}

We showed the ompA and $p$-ompA genes of $Y$. enterocolitica were highly conserved in pathogenic strains; specially, the two genes showed a high correlation with $y s t B$ in biotype 1A strains. The pathogenic and non-pathogenic strains, highly and weakly pathogenic strains were divided into different groups based on sequence polymorphism analysis of the two genes, which reflected the different bio-serotype distributions of $Y$. enterocolitica.

\section{Methods}

Bacterial strains and identification of biotype and serotype

The bacterial strains used in this study were screened from the Chinese Yersinia enterocolitica library which contains nearly 4,000 strains gathered by our laboratory and derived from diarrhea patients, food, animals, and the environment. Strains were selected to cover different isolation dates, different hosts, and separated locations. We 
Table 4 The information of $Y$. enterocolitica used in this study

\begin{tabular}{|c|c|c|c|c|c|c|c|c|c|c|c|c|c|c|c|c|}
\hline \multirow[t]{2}{*}{ Source } & \multicolumn{9}{|c|}{ Pathogenic strains (bio-serotype) } & \multicolumn{6}{|c|}{ Non-pathogenic strains (bio-serotype) } & \multirow[b]{2}{*}{ Total } \\
\hline & $2 / 0: 9$ & 3/0:9 & 4/0:9 & 2/0:3 & $3 / 0: 3$ & 4/0:3 & $\begin{array}{c}2 / 0: 5 \\
27\end{array}$ & 1B/O:8 & Total & 1A/O:3 & 1A/O:8 & 1A/O:9 & 1A/0;5 & $\begin{array}{c}\text { 1A/O:5, } \\
27\end{array}$ & $1 \mathrm{~A} / \mathrm{UN}$ & \\
\hline $\begin{array}{l}\text { Diarrhea } \\
\text { patients }\end{array}$ & 7 & 4 & & & 14 & 2 & & & 27 & & 1 & 1 & 2 & & 4 & 8 \\
\hline Swine & 34 & 3 & & & 51 & & & & 88 & & 18 & 4 & 4 & & 39 & 65 \\
\hline Dogs & 2 & & & 1 & 5 & & & & 8 & & 2 & & & & 7 & 9 \\
\hline Rats & 19 & & & & & & & & 19 & & 2 & & 2 & 2 & 1 & 7 \\
\hline Sheep & & & & 1 & & & & & 1 & & 2 & 2 & & 2 & 6 & 12 \\
\hline Cows & & & & & & & & & & 3 & 10 & 2 & & & 4 & 19 \\
\hline Fish & & & & & 1 & & & & 1 & & & & & & & \\
\hline Chickens & 1 & 1 & & & & & & & 2 & & 5 & 2 & 2 & & 6 & 15 \\
\hline Ducks & & & & & & & & & & & & & 1 & & 2 & 3 \\
\hline Sparrows & & & & & & & & & & & 1 & & & & & 1 \\
\hline Flies & & & & & & & & & & & 1 & & & & 1 & 2 \\
\hline Food & 3 & & & & & & & & 3 & & 3 & 1 & & & 3 & 7 \\
\hline Environment & 1 & & & & & & & & 1 & & & & & & & \\
\hline $\begin{array}{l}\text { Reference } \\
\text { strains }\end{array}$ & & & 1 & & 5 & 3 & 2 & 5 & 16 & & & & & & & \\
\hline $\begin{array}{l}\text { Sequence } \\
\text { strains }\end{array}$ & $1^{\mathrm{a}}$ & $1^{\mathrm{b}}$ & & & & $1^{c}$ & & $1^{d}$ & 4 & & & & & & & \\
\hline Total & 68 & 9 & 1 & 2 & 76 & 6 & 2 & 6 & 170 & 3 & 45 & 12 & 11 & 4 & 73 & 148 \\
\hline
\end{tabular}

a: Y. enterocolitica W22703, contig 7180000001374, GenBank: FR718562.1; b: Y. enterocolitica subsp. palearctica 105.5R (r), complete genome, GenBank: CP002246.1; c: Y. enterocolitica subsp. palearctica Y11, GenBank: FR729477.2; d: Y. enterocolitica subsp. enterocolitica 8081 complete genome, GenBank: AM286415.1; UN: undetermined serotype.

chose 150 pathogenic and 148 biotype $1 \mathrm{~A}$ Y. enterocolitica strains isolated from China; 16 pathogenic reference strains from Europe, United States, and Japan; and four pathogenic complete-genome-sequenced strains (Table 4). The serotypes of these strains were determined as previously described [1,34-36], and the biotypes of strains were identified using the scheme reviewed by Bottone [37]. The pathogenic strains were positive for all genes $\left(\mathrm{ail}^{+}, y s t A^{+}\right.$, $\operatorname{vir} F^{+}$, and $y a d A^{+}$); however, some pathogenic strains lost the plasmid virulence genes for virF and $\operatorname{yad} A$, but still had ail and ystA genes located on the chromosome, the non-pathogenic strain was negative for all these genes.

The sample collection and detection protocols were approved by the Ethics Review Committee from the National Institute for Communicable Disease Control and Prevention, Chinese Center for Disease Control and Prevention.

\section{Primer design}

Two genes for OmpA of $Y$. enterocolitica reference strain 8081 (NC_008800.1) were shown when we searched the NCBI web, one was ompA, another was $p$-ompA. Therefore, we designed the primers of the two genes by using CloneManager software 4.0, and the primers were showed in Table 5. Primers were synthesized by Shanghai Sangon Biological Engineering \& Technology and Service Co., Ltd, China.

\section{PCR, DNA sequencing and sequence analysis}

Bacteria were cultured as previously described [35]. The bacterial DNA was extracted using a Blood \& Tissue Kit (QIAGEN, USA). PCR was performed in a $20 \mu \mathrm{l}$ volume containing $10 \mu \mathrm{l}$ PCR premix (TaKaRa, Japan), $8 \mu$ l ultrapure water, $0.5 \mu \mathrm{l}$ of each forward and reverse primer

Table 5 Primers and annealing temperatures for ompA and $p$-ompA

\begin{tabular}{|c|c|c|c|c|c|c|}
\hline Target gene & Primer direction & Primer Sequences $\left(5^{\prime} \rightarrow 3^{\prime}\right)$ & GenBank no. & Location & Amplicon lengt & Annealing temp \\
\hline \multirow[t]{2}{*}{ ompA } & Forward & ACATCACACTTGTAACTTTCTCACC & YP_001005874.1 & $1783285-1783261$ & $1451 \mathrm{bp}$ & $58^{\circ} \mathrm{C}$ \\
\hline & Reverse & AGAAGTATCAGAATCAGATGTCGTC & & $1781835-1781859$ & & \\
\hline \multirow[t]{2}{*}{ p-ompA } & Forward & GCGGCAAATTCCGTACAGTG & YP_001006877.1 & 2919405-2919386 & $1560 \mathrm{bp}$ & $60^{\circ} \mathrm{C}$ \\
\hline & Reverse & CAGCCCACCAGCAATATTCG & & 2917806-2917825 & & \\
\hline
\end{tabular}


(25 $\mu \mathrm{mol} / \mathrm{l})$, and $10 \mathrm{ng}$ DNA template. Thermal cycling was performed in a MJ PTC200 (Bio-Rad, USA) and the conditions were: denaturation at $94^{\circ} \mathrm{C}$ for $5 \mathrm{~min}$, followed by 25 cycles of melting at $94^{\circ} \mathrm{C}$ for $25 \mathrm{~s}$, annealing for $30 \mathrm{~s}$ at various temperatures depending on the primers used (Table 5), elongation at $72^{\circ} \mathrm{C}$ for $30 \mathrm{~s}$, and a final extension at $72^{\circ} \mathrm{C}$ for $10 \mathrm{~min}$. The specific PCR products were purified using a Gel Extraction Kit (QIAGEN, USA) and sequenced at TaKaRa Biotechnology (Dalian) Co., Ltd. Nucleotide sequence alignments and cluster tree construction were performed using MEGA (Version 4). The statistical tests were performed using statistical analysis software SAS version 9.2 (Statistics Analysis System).

The different sequences of two genes were translated to predict amino acid by MEGA 4.0 software, and the second structure of the proteins were predicted by PredictProtein (http://www.predictprotein.org); the tertiary structure of proteins were predicted and analyzed by SWISS-MODEL (http://swissmodel.expasy.org/workspace).

\section{Availability of supporting data}

All types of patterns for ompA and p-ompA of Yersinia enterocolitica in our study were uploaded to LabArchives (http://www.labarchives.com/bmc) Electronic Laboratory Notebook. All sequences can be shared from the following links:

ompA sequences:

https://mynotebook.labarchives.com/share/hqjing/ MjAuOHwzMjk5OC8xNi0yL1RyZWVOb2RILzMwNjA0MzQxNDh8NTIuOA=DOI:10.6070/H4MP517C. p-ompA sequences:

https://mynotebook.labarchives.com/share/hqjing/

MjIuMXwzMjk5OC8xNy00L1RyZW-

VOb2RILzQwMDM0NDM2MTB8NTYuMQ= DOI:10.6070/H4GX48HN.

\section{Competing interests}

All the authors declare that they have no competing interests.

\section{Authors' contributions}

$\mathrm{KL}, J \mathrm{~L}$ and $H Y$ performed the experimental jobs of the study. $Y X$ and $H Q$ provided the bacterial strain and strain isolation history. WG analyzed the data and wrote the manuscript. XW analyzed the data. HJ designed the experiment and participated in discussion of the study. All authors have read and approved the manuscript.

\section{Acknowledgements \\ This work was supported by the National Natural Science Foundation of China (General Project, no. 30970094 and 31100101) and the National Sci-Tech Key Project (2012ZX10004-201, 2013ZX10004203-2). We thank Liuying Tang and Jim Nelson for critical reading and helpful comments on our manuscript. We would like to acknowledge the technical assistance of Zhigang Cui.}

\section{Author details}

${ }^{1}$ National Institute for Communicable Disease Control and Prevention, Chinese Center for Disease Control and Prevention, State Key Laboratory for Infectious Disease Prevention and Control, Collaborative Innovation Center for Diagnosis and Treatment of Infectious Diseases, 102206 Beijing, China.
${ }^{2}$ Yunnan Provincial Centre for Disease Control and Prevention, 650022 Kunming, China.

Received: 20 March 2013 Accepted: 10 March 2014

Published: 16 March 2014

\section{References}

1. Bottone EJ: Yersinia enterocolitica: the charisma continues. Clin Microbiol Rev 1997, 10(2):257-276.

2. Cover TL, Aber RC: Yersinia enterocolitica. N Engl J Med 1989, 321(1):16-24.

3. Bhagat N, Virdi JS: Distribution of virulence-associated genes in Yersinia enterocolitica biovar $1 \mathrm{~A}$ correlates with clonal groups and not the source of isolation. FEMS Microbiol Lett 2007, 266(2):177-183.

4. Bottone EJ: Yersinia enterocolitica: overview and epidemiologic correlates. Microbes Infect 1999, 1(4):323-333.

5. Cornelis GR, Boland A, Boyd AP, Geuijen C, Iriarte M, Neyt C, Sory MP, Stainier I: The virulence plasmid of Yersinia, an antihost genome. Microbiol Mol Biol Rev 1998, 62(4):1315-1352.

6. Revell PA, Miller VL: Yersinia virulence: more than a plasmid. FEMS Microbiol Lett 2001, 205(2):159-164.

7. Batzilla J, Heesemann J, Rakin A: The pathogenic potential of Yersinia enterocolitica 1A. Int J Med Microbiol 2011, 301(7):556-561.

8. Nikaido $\mathrm{H}$ : Molecular basis of bacterial outer membrane permeability revisited. Microbiol Mol Biol Rev 2003, 67(4):593-656.

9. Smith SG, Mahon V, Lambert MA, Fagan RP: A molecular Swiss army knife: OmpA structure, function and expression. FEMS Microbiol Lett 2007, 273(1):1-11.

10. Soulas C, Baussant T, Aubry JP, Delneste Y, Barillat N, Caron G, Renno T, Bonnefoy $J Y$, Jeannin P: Outer membrane protein A (OmpA) binds to and activates human macrophages. J Immunol 2000, 165(5):2335-2340.

11. Singh R, Shasany AK, Aggarwal A, Sinha S, Sisodia BS, Khanuja SP, Misra R: Low molecular weight proteins of outer membrane of Salmonella typhimurium are immunogenic in Salmonella induced reactive arthritis revealed by proteomics. Clin Exp Immunol 2007, 148(3):486-493.

12. Lee JS, Jung ID, Lee CM, Park JW, Chun SH, Jeong SK, Ha TK, Shin YK, Kim DJ, Park YM: Outer membrane protein a of Salmonella enterica serovar Typhimurium activates dendritic cells and enhances Th1 polarization. BMC Microbiol 2010, 10:263.

13. Gu W, Wang X, Qiu H, Luo X, Xiao D, Xiao Y, Tang L, Kan B, Jing H: Comparative antigenic proteins and proteomics of pathogenic Yersinia enterocolitica bio-serotypes 1B/O: 8 and 2/O: 9 cultured at 25 degrees $C$ and 37 degrees C. Microbiol Immunol 2012, 56(9):583-594.

14. Krishnan S, Prasadarao NV: Outer membrane protein A and OprF: versatile roles in Gram-negative bacterial infections. FEBS J 2012, 279(6):919-931.

15. Poolman JT: Bacterial outer membrane protein vaccines. The meningococcal example. Adv Exp Med Biol 1996, 397:73-77.

16. Pornwiroon W, Bourchookarn A, Paddock CD, Macaluso KR: Proteomic analysis of Rickettsia parkeri strain portsmouth. Infect Immun 2009, 77(12):5262-5271.

17. Singh SP, Williams YU, Miller S, Nikaido H: The C-terminal domain of Salmonella enterica serovar typhimurium $\mathrm{OmpA}$ is an immunodominant antigen in mice but appears to be only partially exposed on the bacterial cell surface. Infect Immun 2003, 71(7):3937-3946.

18. Pascale J, Toufic R, Liliane G, Isabelle M, Jean-Pierre A, Yves D, Nathalie $H$, Thierry B, Giovanni M, Caroline S, Pedro R, Jean-Charles C, Jean-Yves B: OmpA targets dendritic cells, induces their maturation and delivers antigen into the MHC class I presentation pathway. Nat Immunol 2000, 1(6):502-509.

19. Bartra SS, Gong X, Lorica CD, Jain C, Nair MK, Schifferli D, Qian L, Li Z, Plano GV, Schesser K: The outer membrane protein $\mathrm{A}(\mathrm{OmpA})$ of Yersinia pestis promotes intracellular survival and virulence in mice. Microb Pathog 2012, 52(1):41-46.

20. Mclntyre M, Nnochiri E: A case of hospital-acquired Yersinia enterocolitica gastroenteritis. J Hosp Infect 1986, 7(3):299-301.

21. Greenwood MH, Hooper WL: Excretion of Yersinia spp. associated with consumption of pasteurized milk. Epidemiol Infect 1990, 104(3):345-350

22. Brewer RA, Corbel MJ: Characterization of Yersinia enterocolitica strains isolated from cattle, sheep and pigs in the United Kingdom. J Hyg 1983, 90(3):425-433.

23. Corbel MJ, Brewer RA, Hunter D: Characterisation of Yersinia enterocolitica strains associated with ovine abortion. Vet Rec 1990, 127(21):526-527. 
24. Corbel MJ, Ellis B, Richardson C, Bradley R: Experimental Yersinia enterocolitica placentitis in sheep. Br Vet J 1992, 148(4):339-349.

25. Das AM, Paranjape VL, Winblad S: Yersinia enterocolitica associated with third trimester abortion in buffaloes. Trop Anim Health Prod 1986, 18(2):109-112

26. Grant T, Bennett-Wood V, Robins-Browne RM: Identification of virulenceassociated characteristics in clinical isolates of Yersinia enterocolitica lacking classical virulence markers. Infect Immun 1998, 66(3):1113-1120.

27. Grant T, Bennett-Wood V, Robins-Browne RM: Characterization of the Interaction between Yersinia enterocolitica Biotype 1A and Phagocytes and Epithelial Cells In Vitro. Infect Immun 1999, 67(9):4367-4375.

28. Burnens AP, Frey A, Nicolet J: Association between clinical presentation, biogroups and virulence attributes of Yersinia enterocolitica strains in human diarrhoeal disease. Epidemiol Infect 1996, 116:27-34.

29. Ramamurthy T, Yoshino K, Huang X, Balakrish Nair G, Carniel E, Maruyama T, Fukushima H, Takeda T: The novel heat-stable enterotoxin subtype gene (ystB) of Yersinia enterocolitica: nucleotide sequence and distribution of the yst genes. Microb Pathog 1997, 23(4):189-200.

30. Robins-Browne RM, Takeda T, Fasano A, Bordun AM, Dohi S, Kasuga H, Fang G, Prado V, Guerrant RL, Fong G: Assessment of enterotoxin production by Yersinia enterocolitica and identification of a novel heat-stable enterotoxin produced by a noninvasive $Y$. enterocolitica strain isolated from clinical material. Infect Immun 1993, 61(2):764-767.

31. Kot B, Piechota M, Jakubczak A: Analysis of occurrence of virulence genes among Yersinia enterocolitica isolates belonging to different biotypes and serotypes. Pol J Vet Sci 2010, 13(1):13-19.

32. Singh I, Virdi JS: Production of Yersinia stable toxin (YST) and distribution of yst genes in biotype 1A strains of Yersinia enterocolitica. Indian J Med Microbiol 2004, 53(Pt 11):1065-1068.

33. Nakano M, Yamasaki E, Ichinose A, Shimohata T, Takahashi A, Akada JK, Nakamura K, Moss J, Hirayama T, Kurazono H: Salmonella enterotoxin (Stn) regulates membrane composition and integrity. Dis Model Mech 2012, 5(4):515-521.

34. Wang X, Cui Z, Jin D, Tang L, Xia S, Wang H, Xiao Y, Qiu H, Hao Q, Kan B, Xu J, Jing H: Distribution of pathogenic Yersinia enterocolitica in China. Eur J Clin Microbiol Infect Dis 2009, 28(10):1237-1244.

35. Wang X, Qiu H, Jin D, Cui Z, Kan B, Xiao Y, Xu Y, Xia S, Wang H, Yang J, Wang $X$, Hu W, Xu J, Jing H: O:8 serotype Yersinia enterocolitica strains in China. Int J Food Microbiol 2008, 125(3):259-266.

36. Thoerner P, Bin Kingombe Cl, Bogli-Stuber K, Bissig-Choisat B, Wassenaar TM, Frey J, Jemmi T: PCR detection of virulence genes in Yersinia enterocolitica and Yersinia pseudotuberculosis and investigation of virulence gene distribution. Appl Environ Microbiol 2003, 69(3):1810-1816.

37. Bottone EJ: Yersinia enterocolitica: a panoramic view of a charismatic microorganism. CRC Crit Rev Microbiol 1977, 5(2):211-241.

doi:10.1186/1471-2164-15-201

Cite this article as: Li et al: Gene polymorphism analysis of Yersinia enterocolitica outer membrane protein A and putative outer membrane protein A family protein. BMC Genomics 2014 15:201.

\section{Submit your next manuscript to BioMed Central and take full advantage of:}

- Convenient online submission

- Thorough peer review

- No space constraints or color figure charges

- Immediate publication on acceptance

- Inclusion in PubMed, CAS, Scopus and Google Scholar

- Research which is freely available for redistribution 